\title{
In the Beginning
}




\title{
Siphrut \\ Literature and Theology of the Hebrew Scriptures
}

\author{
Editorial Board \\ Stephen B. Chapman Duke University \\ TREMPER Longman III Westmont College \\ NATHAN MACDONALD University of Cambridge
}

1. A Severe Mercy: Sin and Its Remedy in the Old Testament, by Mark J. Boda

2. Chosen and Unchosen: Conceptions of Election in the Pentateuch and Jewish-Christian Interpretation, by Joel N. Lohr

3. Genesis and the Moses Story: Israel's Dual Origins in the Hebrew Bible, by Konrad Schmid

4. The Land of Canaan and the Destiny of Israel: Theologies of Territory in the Hebrew Bible, by David Frankel

5. Jacob and the Divine Trickster: A Theology of Deception and YHwH's Fidelity to the Ancestral Promise in the Jacob Cycle, by John E. Anderson

6. Esther: The Outer Narrative and the Hidden Reading, by Jonathan Grossman

7. From Fratricide to Forgiveness: The Language and Ethics of Anger in Genesis, by Matthew R. Schlimm

8. The Rhetoric of Remembrance: An Investigation of the "Fathers" in Deuteronomy, by Jerry Hwang

9. In the Beginning: Essays on Creation Motifs in the Ancient Near East and the Bible, by Bernard F. Batto

10. Run, David, Run! An Investigation of the Theological Speech Acts of David's Departure and Return (2 Samuel 14-20), by Steven T. Mann 


\section{In the Beginning}

\section{Essays on Creation Motifs in the Ancient Near East and the Bible}

Bernard F. Batto

Winona Lake, Indiana

EISENBRAUNS

2013 
(C) 2013 by Eisenbrauns Inc.

All rights reserved

Printed in the United States of America

www.eisenbrauns.com

\section{Library of Congress Cataloging-in-Publication Data}

Batto, Bernard Frank.

[Essays. Selections]

In the beginning : essays on creation motifs in the ancient Near East and the Bible / Bernard F. Batto.

pages $\mathrm{cm}$. - (Siphrut : literature and theology of the Hebrew Scriptures ; 9)

ISBN 978-1-57506-267-9 (alk. paper)

1. Creation-Biblical teaching. 2. Bible. O.T. Genesis I-XI-Criticism, interpretation, etc. 3. Middle East-Religion. 4. Middle Eastern literatureHistory and criticism. I. Title.

BS1199.C73B382 2013

221.6-dc23

2013009703

The paper used in this publication meets the minimum requirements of the American National Standard for Information Sciences-Permanence of Paper for Printed Library Materials, ANSI Z39.48-1984. 